\title{
KONSENTRASI KULIT BAWANG PUTIH ( Allium sativum ) DAN DAUN JERUK \\ PURUT ( Cistrus hystrix ) TERHADAP SIFAT FISIKO KIMIA DAN ORGANOLEPTIK PADA BANDENG PRESTO
}

\author{
Concentration Of Garlic ( Allium Sativum ) Peel and Citrus Hystrix Leaves \\ Against The Physicochemical and Organoleptic Properties Of Presto Milkfish \\ ${ }^{1}$ Muhammad Azhar Rathamy, ${ }^{2}$ Sri Haryati , ${ }^{3}$ Endang Bekti \\ ${ }^{1}$ Mahasiswa Teknologi Hasil Pertanian Universitas Semarang \\ ${ }^{2,3}$ Staff Pengajar Teknologi Hasil Pertanian Universitas Semarang Jl. \\ Soekarno-Hataa Tlogosari Semarang-50196 \\ Azharratomy98@gmail.com
}

\begin{abstract}
ABSTRAK
Bandeng presto (Chanos Chanos Forks) disukai sebagai makanan karena cita rasa yang gurih, rasa daging kenyal, dan mengandung $202.6 \mathrm{kkal}$ energy, $27.10 \%$ protein, 9.98\% lemak, $0.22 \%$ kalsium, dan 58.93\% kadar air. Kulit bawang putih Bandeng presto (Chanos Chanos Forks) disukai sebagai makanan karena cita rasa yang gurih, rasa daging kenyal, dan mengandung $202.6 \mathrm{kkal}$ energy, $27.10 \%$ protein, $9.98 \%$ lemak, $0.22 \%$ kalsium, dan $58.93 \%$ kadar air. Kulit bawang putih mengandung senyawa anti mikroba. Daun jeruk purut mengandung antioksidan sebagai anti mikroba dan senyawa bio aktif seperti minyak atsiri, flavonoid, saponin, dll. Penelitian ini bertujuan untuk mengetahui pengaruh konsentrasi kulit bawang putih dan daun jeruk purut terhadap sifat fisiko kimia dan organoleptik pada bandeng presto. Metode yang digunakan RAK (Rancangan Acak Kelompok) satu factor yaitu konsentrasi kulit bawang putih dan daun jeruk purut, dengan 4 perlakuan 5 kali ulangan. Data yang diperoleh dianalisa dengan menggunakan analisis sidik ragam (ANOVA) dan dilanjut uji BNJ pada taraf $5 \%$.
\end{abstract}

Key words: Garlic peel, Lime leaves, Milkfish presto.

\begin{abstract}
Milkfish presto (Chanos Chanos Forsk) is preferred as a food because of its savorytaste, chewy meat taste and contains $202.6 \mathrm{kkal}$ of energy, 27.10\% protein, $9.98 \%$ fat, $0.22 \%$ calcium, and $58.93 \%$ water content. Garlic peel contains anti-microbial compounds. Lime leaves contain antioxidants as anti-microbial and bio activecompounds such as essential oils, flavonoids, saponins, etc. This study aims to determine the effect of the concentration of the peel of garlic and lime leaves on the physico-chemical and organoleptic properties on the milkfish of presto. The method used RBD (Randomized Block Design) one factor was the concentration of the peel of garlic and lime leaves, with 4 treatments 5 replications. The data obtained were analyzed using analysis of variance (ANOVA) and continued with the BNJ test at $5 \%$ level.
\end{abstract}

Key words: Garlic peel, Lime leaves, Milkfish presto. 


\section{PENDAHULUAN}

Bandeng presto ( Chanos chanos forks ) merupakan suatu produk olahan dengan metode pemasakan dengan tekanan tinggi (presto) yang memiliki rasa enak, gurih, kaya akan kandungan gizi, protein, dan harganya yang terjangkau sehingga banyak digemari masyarakat. Bandeng merupakan ikan yang memiliki banyak duri sebagai salah satu kelemahannya, sudah teratasi dengan metode pengolahan presto sehingga dapat dikonsumsi dengan durinya yang sudah lunak. Namun ada kelemahan pada bandeng presto yang lain yaitu lama simpan pada suhu ruang. Bandeng presto dengan aneka rempah rempah seperti bawang putih, lengkuas, kunyit, jahe, garam, dll mampu bertahan 3 hari dalam penyimpanan suhu ruang, 6 hari dalam kulkas.

Limbah dianggap sebagai sesuatu yang tidak berguna dan jika dibiarkan terlalu lama akan terdapat banyak penimbunan, pemandangan yang tidak sedap dan juga sebagai sarang penyakit (Nisak dan Karyaningrum, 2013). Kulit bawang putih dianggap limbah oleh masyarakat karena belum diketahui kegunaan, manfaat, ataupun kandungan gizinya.

Kulit bawang putih merupakan lapisan luar dari umbi bawang putih yang melindunginya dari penuaan. Hal ini dibuktikan banyak dijumpai bawang putih dengan kulit belum dikupas dapat bertahan lebih lama selama penyimpanan dibanding bawang putih yang telah dikupas. Hal ini memperlihatkan bahwa kulit bawang putih mempunyai senyawa aktif seperti anti mikroba yang melindungi umbinya. Kulit bawang putih kaya akan vitamin A, C, dan E serta antioksidan yang melindungi sel-sel kulit dari kerusakan radikal bebas. Sitrus atau yang dikenal dengan jeruk adalah salah satu tanaman yang mempunyai nilai ekonomi tinggi karena mengandung vitamin $\mathrm{C}$ dan digunakan sebagai penyedap masakan. Terdapat senyawa bioaktif seperti minyak atsiri, flavonoid, saponin, dan steroid dalam daun jeruk (Hebert dkk., 2014). Bahan aktif yang penting bagi kesehatan yang terdapat dalam daun jeruk adalah vitamin $\mathrm{C}$, flavonoid, karotenoid,

limonoid, dan mineral. Flavonoid merupakan bahan antioksidan yang mampu menetralisir oksigen reaktif dan berkontribusi terhadap pencegahan penyakit kronis seperti kanker (Devy, 2010).

Oleh sebab itu, berdasarkan latar belakang diatas, diduga dengan menambahkan konsentrasi kulit bawang putih dan daun jeruk purut yang mengandung senyawa anti mikroba dapat menekan pertumbuhan bakteri pada bandeng presto. Hal yang menarik peneliti untuk melakukan penelitian dengan menggunakan perbedaan konsentrasi kulit bawang putih dan daun

jeruk purut akan mempengaruhi mikro mikrobiologi (TPC), sifat fisik, sifat kimia dan organoleptic. 


\section{RUMUSAN MASALAH, TUJUAN, IPOTESIS}

Apakah konsentrasi kulit bawang puth dan daun jeruk purut mempengaruhi fisikokimia dan organoleptik bandeng presto yang dihasilkan?

Penelitian ini bertujuan untuk mengetahui pengaruh konsentrasi kulit bawang putih dan daun jeruk purut terhadap sifat kimia dan organoleptik (rasa, warna, aroma, tekstur) pada bandeng presto.

Diduga konsentrasi kulit bawang puth dan daun jeruk purut pada pembuatan bandeng presto berpengaruh terhadap sifat fisik, kimia dan organoleptik.

\section{METODE PENELITIAN}

\section{Waktu dan Tempat Penelitian}

Penelitian ini dilaksanakan di Laboratorium Rekayasa Pangan, Laboratorium Kimia dan Biokimia, Laboratorium Uji Inderawi Fakultas Teknologi Pertanian Universitas Semarang. Penelitian dilakukan selama 3 bulan.

\section{Alat dan Bahan Penelitian}

Bahan baku untuk penelitian ini yaitu bandeng presto, kulit bawang putih, daun jeruk purut, daun pisang, air, garam, $\mathrm{K}_{2} \mathrm{SO}_{4}, \mathrm{HgO}, \mathrm{H}_{2} \mathrm{SO}_{4}, \mathrm{NaOH} 40 \%, \mathrm{H}_{2} \mathrm{BO}_{3}, \mathrm{HCl}$, indikator pp dan aquades.

Alat yang di gunakan pada pembuatan kamaboko adalah pisau, timbangan, baskom, pengaduk, kompor, autoclave, sendok, destilasi, oven, desikator, kondensor, erlenmeyer, labu kjeldahl dan CT3 Brookfield tekstur analyzer.

\section{RANCANGAN PERCOBAAN}

Rancangan percobaan yang digunakan dalam penelitian ini adalah Rancangan Acak Kelompok (RAK) satu faktor dengan 4 perlakuan dan 5 kali ulangan sebagai berikut :

P1: Konsentrasi Kulit Bawang Putih 0,5\% Dan Daun Jeruk Purut 0,5\%.

P2: Konsentrasi Kulit Bawang Putih 1\% Dan Daun Jeruk Purut 1\%.

P3: Konsentrasi Kulit Bawang Putih 1,5\% Dan Daun Jeruk Purut 1,5\%.

P4: Konsentrasi Kulit Bawang Putih 2\% Dan Daun Jeruk Purut 2\%.

\section{Prosedur Penelitian}

Bandeng presto dicuci dengan air bersih lalu dibersihkan isi perut dan insang. Ikan bandeng di rendam pada air garam selama 5-10 menit. Kulit bawang putih dan daun jeruk purut di blender kemudian di oleskan secara merata pada ikan bandeng hingga menutupi seluruh permukaan ikan bandeng. Daun pisang dimasukkan ke dalam autoclave sebagai alas ikan bandeng. Ikan bandeng di presto selama 90 menit dengan suhu $115^{\circ} \mathrm{C}$ bandeng presto yang sudah matang di di dinginkan dengan suhu ruang.

\section{HASIL DAN PEMBAHASAN}

\section{Kadar Air Hari 1}

Berdasarkan analisa ragam menunjukkan bahwa perbedaan konsentrasi kulit bawang putih dan daun jeruk purut tidak berpengaruh nyata terhadap kadar air bandeng presto hari 1. Hasil analisa kadar air hari 1 dapat dilihat pada grafik rerata kadar air hari 1 setelah diuji lanjut dengan BNJ 5\% menunjukkan tidak ada perbedaan yang nyata antar perlakuan. 


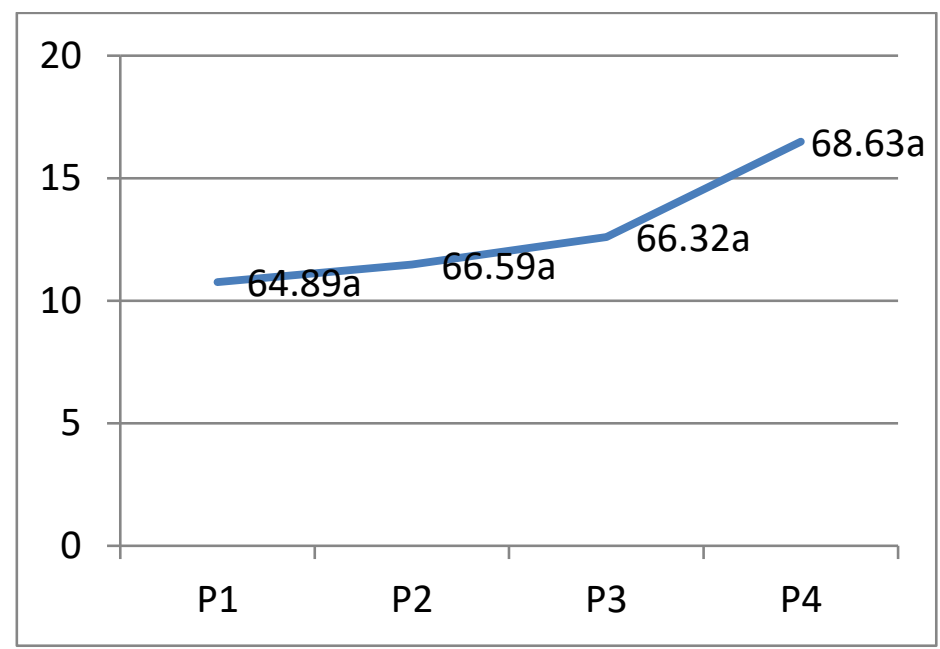

Gambar 1. Grafik Rerata Kadar Air Hari 1

Penggunaan konsentrasi kulit bawang putih dan daun jeruk tidak berpengaruh nyata terhadap kadar air bandeng presto pada hari ke-1. Hal itu disebabkan penggunaan bandeng pada semua perlakuan juga memiliki kadar airnya masing-masing, maka dari itu hasil rerata tiap perlakuan memiliki variasi nilai yang berbeda-beda. Penambahan kulit bawang dan daun kulit jeruk berfungsi sebagai antioksidan dan menciptakan cita rasa pada bandeng presto.

\section{Kadar Air Hari 6}

Berdasarkan analisa ragam menunjukkan bahwa perbedaan konsentrasi kulit bawang putih dan daun jeruk purut tidak berpengaruh nyata terhadap kadar air bandeng presto hari 6. Kadar air hari 6 mengalami penurunan dibanding pada kadar air hari 1, hal ini dipengaruhi suhu ruang, lama penyimpanan 6 hari dan lingkungan penyimpanan. Perhitungan rata-rata kadar air hari 6 bandeng presto dapat dilihat pada Grafik berikut.

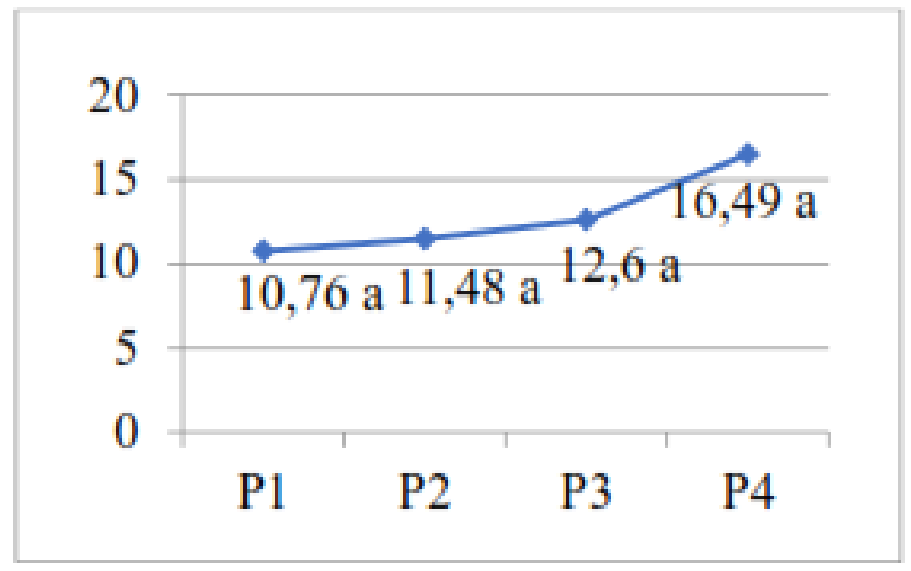

Gambar 2. Grafik Rerata Kadar Air Hari 6 
Penggunaan konsentrasi kulit bawang putih dan daun jeruk purut tidak berpengaruh nyata terhadap kadar air bandeng presto pada hari 6. Hal itu disebabkan penggunaan konsentrasi kulit bawang putih dan daun jeruk purut pada bandeng presto di semua perlakuan memiliki kadar airnya masing-masing, maka dari itu hasil rerata tiap perlakuan memiliki variasi nilai yang berbeda-beda.

\section{Tekstur}

Berdasarkan analisa ragam menunjukkan bahwa konsentrasi kulit bawang putih dan daun jeruk purut tidak berpengaruh nyata terhadap tekstur bandeng presto. Hal ini berkaitan dengan

kadar air hari 1 maupun hari 6 yang ternyata tidak berpengaruh nyata pada bandeng presto. Sehingga tekstur juga tidak ada beda nyata di semua perlakuan. Perhitungan ratarata tekstur bandeng presto dapat dilihat pada Grafik berikut.

Penggunaan konsentrasi kulit bawang putih dan daun jeruk purut dengan perlakuan konsentrasi yang berbeda tidak berpengaruh nyata terhadap tekstur bandeng presto. Hal itu dikarenakan daun jeruk purut dan kulit bawang putih hanya berfungsi sebagai pembentuk cita rasa pada bandeng presto dan pada kadar air hari ke- 1 dam ke-6 tidak mengalami pengaruh yang nyata maka dari itu pada tekstur tidak mengalami pengaruh yang berbeda nyata.

\section{TPC}

Berdasarkan hasil analisis sidik ragam menunjukkan bahwa konsentrasi kulit bawang putih dan daun jeruk purut berpengaruh nyata $(\mathrm{p}<0.05)$ terhadap TPC pada bandeng presto. Setelah diuji lanjut dengan BNJ pada taraf 5\% menunjukkan bahwa ada beda nyata pada perlakuan. Rerata hasil analisis TPC pada bandeng presto dapat dilihat pada Grafik berikut.

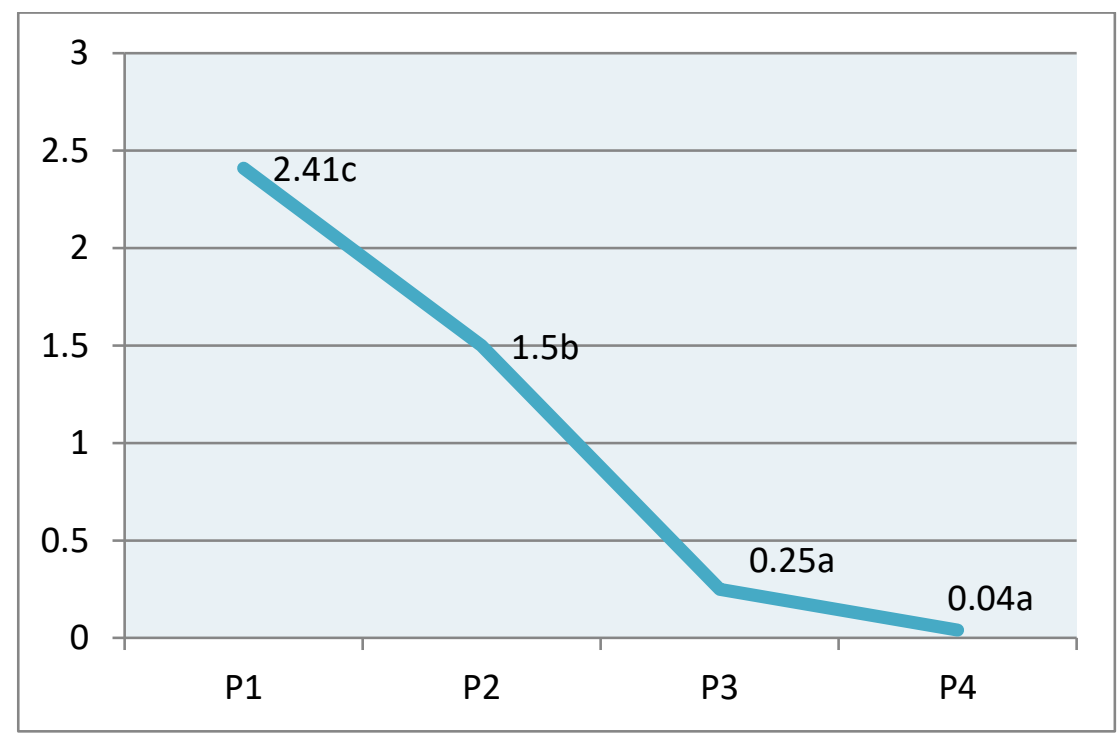

Gambar 3. Grafik Rerata TPC Bandeng Presto 
Tinggi rendahnya TPC pada bandeng presto dapat dipengaruhi oleh penambahan konsentrasi kulit bawang putih dan daun jeruk purut. Semakin banyak penambahan konsentrasi kulit bawang putih dan daun jeruk purut maka TPC akan semakin rendah karena kulit bawang putih dan daun jeruk purut berperan sebagai anti mikroba sehingga mampu menghambat atau membunuh mikroba yang tumbuh seperti, jamur (kapang atau khamir), bakteri staphyloccusaureus yaitu bakteri kontaminan yang bersifat termostabil yang biasanya tumbuh pada produk olahan daging, ikan, dll yang disimpan dalam jangka waktu tertentu.

\section{Uji Organoleptik Rasa}

Rasa merupakan salah satu faktor utama yang menarik perhatian konsumen terhadap bahan makanan. Rasa terbentuk dari perpaduan komposisi bahan makanan yang digunakan dalam bahan makanan. Rasa banyak melibatkan panca indera lidah. Umumnya makanan tidak hanya terdiri dari satu kelompok rasa saja, tetapi merupakan gabungan dari berbagai rasa yang terpadu sehingga menimbulkan rasa yang enak. Rasa secara umum dapat dibedakan menjadi empat yaitu asin, asam, manis dan pahit (Winarno, 2007).

Hasil uji organoleptik yang dilakukan oleh 20 mahasiswa dari program studi S1. Teknologi Hasil Pertanian Universitas semarang yang dianggap memiliki kompetensi lebih baik

dibandingkan mahasiswa biasa. Berdasarkan analisa varian menunjukkan bahwa penambahan kulit bawang putih dan daun jeruk berpengaruh nyata $(p<0,05)$ terhadap rasa. Setelah di uji BNJ

pada taraf $5 \%$ diperoleh hasil seperti pada tabel 12 serta perhitungan SPSS dapat dilihat pada Grafik berikut.

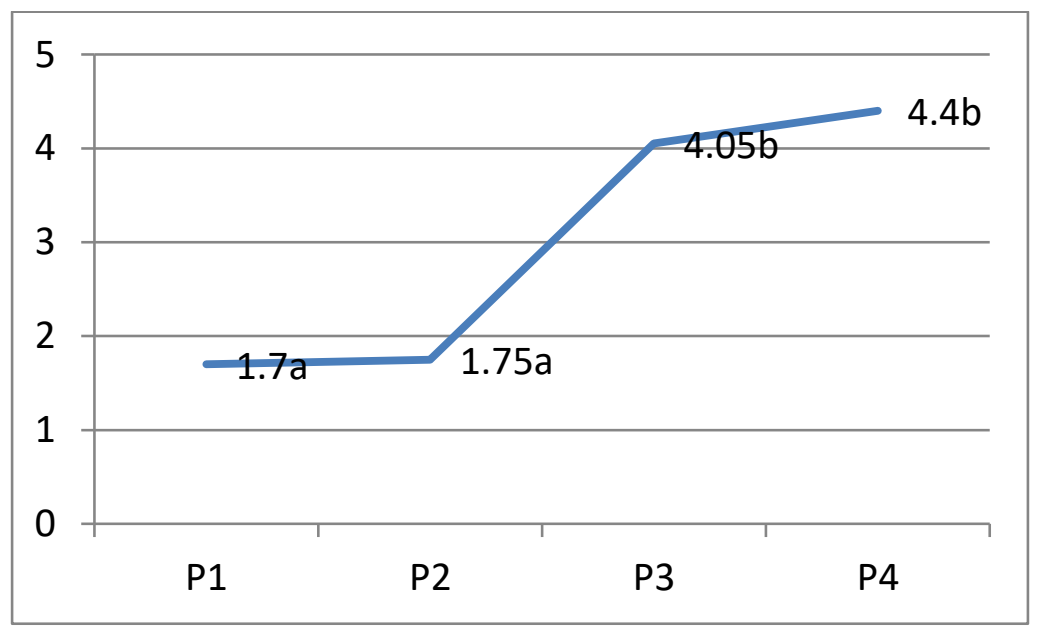

Gambar 4. Grafik Rerata Uji Organoleptik Rasa

Grafik menunjukan persentase nilai rerata skor kesukaan rasa bandeng presto berkisar antara 1,70\% - 4,40\% dengan tidak terasa bawang putih dan daun jeruk hingga sangat terasa bawang putih dan daun jeruk. Hasil skor rasa bandeng presto tertinggi adalah $4,40 \%$ dengan kriteria sangat terasa bawang putih dan daun jeruk yang diperoleh dari perlakuan 4 dengan penambahan kulit bawang putih dan daun jeruk masing-masing sebanyak 20 gram. Karena semakin banyak penambahan kulit bawang putih dan daun jeruk akan memperkuat cita rasa pada bandeng presto. 
Daun jeruk purut purut berkhasiat stimulant dan penyegar. stimulant, berbau khas aromatik, rasanya agak asin sedangkat kulit bawang memberi peran penambah rasa bawang. Sehingga semakin banya penambahan konsentrasi kulit bawang putih dan daun jeruk purut maka cita rasa yang yang dihasilkan semakin enak. Maka pada p4 menghasilkan skor rasa tertinggi.

Kemudian skor terendah diperoleh dari perlakuan 1 dengan rerata $1,70 \%$ yaitu menggunakan konsentrasi kulit bawang 5 gram dan konsentrasi daun jeruk purut 5 gram. Hal itu karena dipengaruhi oleh tingkat kesukaan tekstur bandeng presto, sehingga juga mempengaruhi tingkat kesukaan rasa bandeng presto. Semakin tinggi tingkat kesukaan pada rasa maka semakin tinggi juga tingkat kesukaan pada tekstur bandeng presto.

\section{Uji Organoleptik Aroma}

Aroma merupakan suatu hal yang menjadi daya Tarik tersendiri dalam menentukan rasa enak dari suatu produk makanan. Industi pangan menganggap sangat penting untuk melakukan uji terhadap $\mathrm{H}$ dengan cepat memberikan produknya disukai atau tidak disukai (Soekarto, 1985).

Aroma merupakan ciri lain yang penting dalam menilai tingkat penerimaan konsumen terhadap suatu produk pangan. Aroma daging segar tidak berbau busuk atau masam, tetapi berbau khas daging segar. Bau daging dipengaruhi oleh jenis hewan, pakan, umur daging, jenis kelamin, lama waktu dan kondisi penyimpanan. Indera pembau digunakan untuk menilai bau atau aroma suatu produk pangan.

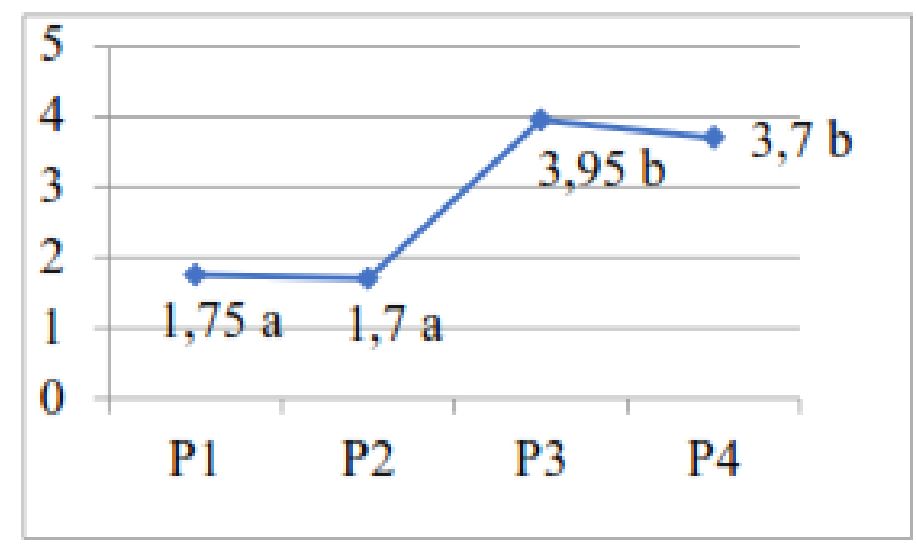

Gambar 5. Grafik Rerata Uji Organoleptik Aroma

Grafik menunjukan semakin banyak penambahan kulit bawang putih dan daun jeruk purut akan memperkuat aroma dari daun jaruk purut. Dalam hal ini, perlakuan 4 merupakan perlakuan

dengan penambahan kulit bawang putih dan daun jeruk purut terbanyak yaitu masingmasing 20 gram. Namun tidak menjadi nilai tertinggi dari kesukaan kesukaan terhadap aroma bandeng presto. Hal ini dapat di sebabkan karena panelis yang digunakan adalah semi professional dan sampel diacak sehingga penelis dapat menilai secara objektif dan jujur. Hasilnya, panelis lebih menyukai aroma dari perlakuan ke 3. Kulit bawang putih dan daun jeruk memiliki aroma yang khas. Pada perlakuan 1 dan perlakuan 2 tidak memiliki perbedaan nilai yang signifikan. Hal itu dikarenakan pada perlakuan 1 menggunakan konsentrasi kulit bawang putih 5 gram dan daun jeruk purut 5 gram sedangkan perlakuan 2 menggunakan masing-masing konsentrasi sebanyak 10 gram. Hasilnya panelis tidak bau aroma dari daun jeruk purut pada perlakuan 2, dan agak bau aroma daun jeruk purut pada perlakuan 1 . 


\section{Uji Organoleptik Warna}

Berdasarkan analisa varian menunjukkan bahwa penambahan kulit bawang putih dan daun jeruk putih berpengaruh nyata $(\mathrm{p}<0,05)$ terhadap warna. Setelah di uji BNJ pada taraf $5 \%$ diperoleh hasil seperti pada Grafik berikut.

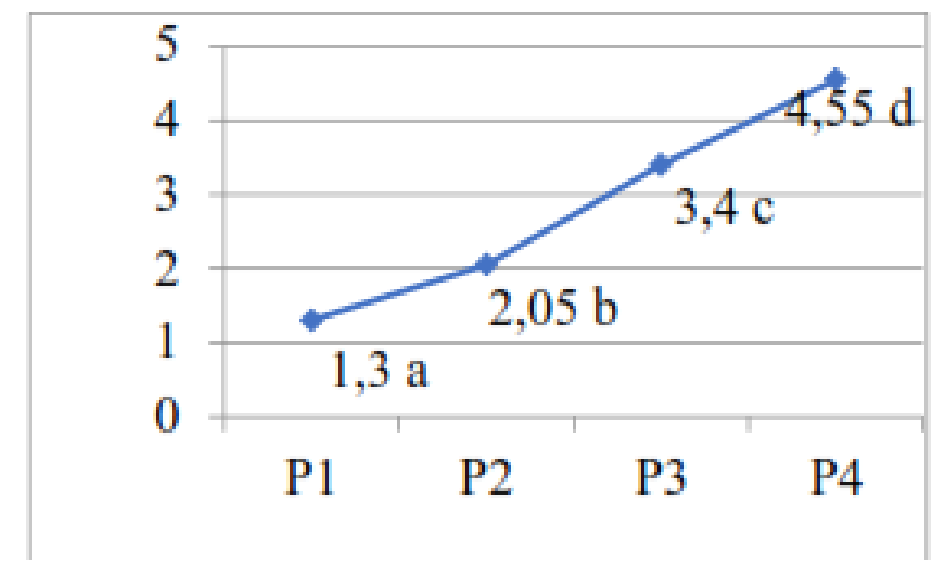

Gambar 6. Grafik Rerata Uji Organoleptik Warna

Grafik diatas menunjukan persentase nilai rerata skor kesukaan warna bandeng presto mengalami kenaikan. Kenaikan intensitas kecerahan maupun penurunan intensitas warna kekuningan atau kepucatan yang terjadi pada bandeng presto disebabkan karena variasi konsentrasi kulit bawang putih dan daun jeruk nipis. kenaikan tingkat kecerahan dan penurunan intensitas warna kekuningan atau kepucatan seiring dengan lamanya masa penyimpanan karena

pengaruh dari metabolit mikroba. Semakin tinggi penambahan konsentrasi kulit bawang dan daun jeruk, maka warna pada bandeng presto semakin disukai panelis.

\section{Uji Organoleptik Kekenyalan}

Berdasarkan hasil analisis sidik ragam menunjukkan bahwa penggunaan kulit bawang putih dan daun jeruk sebagai antioksidan dan antibakeri pada bandeng presto berpengaruh terhadap organoleptik tekstur kekenyalan dari bandeng presto. Grafik menunjukkan ada perbedaan nyata antar perlakuan. Adapun grafik rerata tekstur kekenyalan organileptik bandeng presto sebagai berikut.

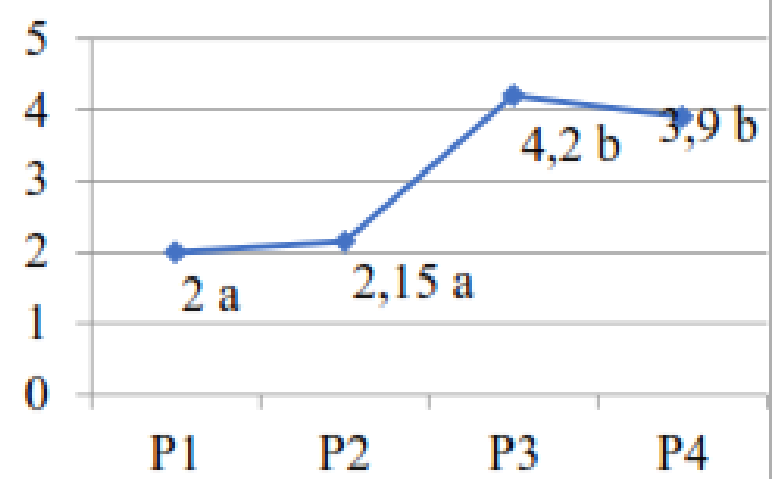

Gambar 7. Grafik Rerata Uji Organoleptik Kekenyalan 


\section{KESIMPULAN}

1. Hasil analisis menunjukkan bahwa konsentrasi dengan jumlah berbeda memberikan pengaruh terhadap jumlah total mikroba (TPC) dan sifat organoleptik rasa, aroma, warna, dan kekenyalan ikan bandeng presto. Akan tetapi, tidak memberikan pengaruh pada sifat fisik kekenyalan daging dan kadar air ikan bandeng.

2. Hasil analisis menunjukkan perlakuan terbaik yaitu P4, dengan parameter yang di uji adalah kadar air (hari 1) 68,63\%, kadar air (hari 6) 16,49\%, tekstur 3413,87 g/f, tpc 0,04x108 CFU/ml dan uji organoleptik mutu hedonik bandeng presto terhadap parameter Rasa dengan skor 4,40 (sangat terasa bawang putih dan daun jeruk purut), Aroma dengan skor 3,70 (sangat bau daun jeruk purut), Warna dengan skor 4,55 (putih kekuningan), Kekenyalan dengan skor 3,90 (kenyal). Perbedaan konsentrasi kulit bawang putih dan daun jeruk purut sangat menentukan mutu yang dihasilkan dari ikan bandeng presto dari segi mikro maupun organoleptik. P4 dengan total konsentrasi $4 \%$ mampu menghambat pertumbuhan mikroba hari ke 6 dengan penyimpanan suhu ruang dengan signifikan yaitu 0,04 (CFU/ml 108 ) dibandingkan dengan P1 dengan total konsentrasi $1 \%$ yang menunjukan hasil cukup tinggi yaitu 2,40x108 CFU/ml. Pada organoleptik (rasa, aroma, warna, kekenyalan) dengan uji mutu hedonik, panelis menunjukan tingkat kesukaannya di hampir semua parameter pada P4.

\section{Saran}

Berdasarkan hasil penelitian ini dapat disarankan untuk :

1. Berdasarkan penelitian yang telah dilakukan, seharusnya penambahan jumlah konsentrasi kulit bawang putih dan daun jeruk purut dapat di tambah lebih banyak agar mampu memaksimalkan umur simpan ikan bandeng presto sampai hari ke 6 sehingga masih layak untuk dikonsumsi. Karena pada P4 dengan total konsentrasi $4 \%$ mampu mempertahankan mutu bandeng dengan kondisi layak konsumsi sampai hari ke 4 .

2. Lingkungan penyimpanan sangat mempengaruhi mutu dari ikan bandeng presto.

\section{DAFTAR PUSTAKA}

AOAC, 1995. Official Methods of Analysis of The Association of Analytical Chemists, Washington D.C.

Adawyah. Rabiatul. 2011. Pengolahan dan pengawetan ikan. Edisi Pertama. PT Bumi Aksara. Jakarta

Arifudin, R. 1983. Bandeng Duri lunak dalam kumpulan Hasil Penelitian Teknologi Pasca panen perikanan. BPTP. Jakarta.

Ankri, S. and D. Mirelman. 1999. Antibicrobial properties of allicin from garlic. microbes and infect. 2:125-129.

Astawan, Made, 2006. Mengenal Formalin Dan Bahayanya. Jakarta: Penebar Swadaya.

Brady, J. E 1999. Kimia Universitas Asas dan strucktur Binarupa Aksara . Jakarta.

Basmal, Bagus, Utomo dan Taylor. 1997. Pengaruh Perebusan, Penggaraman, Penyimpanan Terhadap Penurunan Kandungan Lisin Yang Terhadap Dalam Ikan Pindang. J. Penelitian Perikanan Indonesia. 3(2)

Devy, R. 2010. Food Processing and impact on nutrition. Scholars and Veterinary sciences . 2 (4A): 304-311

Djarijah, R. M. 1995. Ikan Duri Lunak. Kanisius.Yogyakarta.

Hebert, Subagyo Yotopranoto, Hamidah. 2014 Efektivitas Ekstrak Daun Jeruk Purut (Citrus hystrix), Jeruk Purut limau ( citrus amblycarpo), dan jeruk bali ( citrus maxima) Terhadap Larva Aedes aegypti. Jurnal Aspirator, Vol. 6, 
Koswara, S. 2011. Menyuling dan menepungkan minyak atsiri daun jeruk purut. http://www.ebookpangan.com

Koswara, S. 2010. Menyuling dan Menampungkan Minyak Atsiri Daun jeruk purut dan menempungkan minyak/2013/07 teknologi-panganparameter-Proses-Penyulinganminyak-atsiri.htmdiakses 2e November 2017

Lingga ME \& MM Rustama. 2005. Uji Aktivitas Antibakteri dari Ekstrak Air dan Etanol Bawang Putih (Allium sativum L.) terhadap Bakteri Gram Negatif dan Gram Positif yang Diisolasi dari Udang Dogol

(Metapenaeus monoceros), Udang Lobster (Panulirus sp), dan Udang Rebon (Mysis dan Acetes). Jurnal Biotika 5 (2).

Muchtadi. 1989. Evaluasi Nilai Gizi Pangan. Departemen Pendidikan dan Kebudayaan Jenderal Pendidikan PAU Pangan dan Gizi IPB, Bogor.

Maidment, D. C. J,. Z. Dembny and D.I Watts. 2001. The anti-bacterial activity of 12 Alliums against Escherichia coll. Nutrit. And Food Sci.31(5) :238241

Nisak, A. K., Karyaningkrum, A, E., 2013 Pengaruh Perbandingan Jenis Lem terhadap Hasil Jadi Bros dari Limbah Kulit Bawang Putih, ejournal Unesa. Volume 02 Nomer 01, edisi Yudisium Periode Februari , 2530

Ostergaard, A., Ben Embarek, P.K., Yamprayoon, J.,WedelNeer Gaard, C., Huss H.H., Gram, L. 1998. "Fermentation and Spoilage of Som-fak , a Thai Low Salt Fish Product." Trop. Science. 38: 105-112.

Pratiwi. 2008. Mikrobiologi Farmasi. Jakarta: Erlangga. 